\title{
Cultivation of Grafted Vegetables I. Current Status, Grafting Methods, and Benefits
}

\author{
Jung-Myung Lee ${ }^{1}$ \\ Department of Horticulture, Kyung Hee University, Suwon 449-701, Korea
}

\section{INTRODUCTION}

Growing grafted vegetables was first launched in Japan and Korea in the late 1920s by grafting watermelons to gourd rootstock (Ashita, 1927; Yamakawa, 1983). After the first trial, the cultivated area of grafted vegetables, as well as the kinds of vegetables being grafted, has been consistently increased. At present, most of the watermelons [Citrullus lanatus (Thunb.) Matsum. \& Nakai], Oriental melons (Cucumis melo var. makuwa Makino), greenhouse cucumbers (Cucumis sativus L.), and several solanaceous crops in Korea and Japan are grafted before being transplanted to the field or greenhouse (Ito, 1992; Kurata, 1992; Lee,. 1989; Ryu et al., 1973). The purpose of grafting also has been greatly expanded, from reducing infection by soilborne diseases caused by pathogens such as Fusarium oxysporum Schlect. (Choi et al., 1980; Hirata, 1975; Itagi, 1992; Marukawa and Takatsu, 1969; Ryu et al., 1973; Yamakawa, 1983) to increasing low-temperature (Marukawa and Takatsu, 1969; Masuda and Gomi, 1984; Masuda et al., 1981; Tachibana, 1982, 1988, 1989) and salt and wet-soil tolerance (Park, 1987), enhancing water and nutrient uptake (Gomi and Masuda, 1981; Heo, 1991; Jang et al., 1992; Kato and Lou, 1989; Kim and Lee, 1989; Marukawa and Takatsu, 1969; Masuda and Gomi, 1982), and increasing plant vigor and extending the duration of economical harvest time (Itagi, 1992; Ito, 1992; Jeong, 1986; Kim and Lee, 1989), among other purposes (Ali et al., 1991; Chailakhyan and Khrianin, 1987; Dole and Wilkins, 1991; Frankel, 1970; M1atsuzoe et al., 1991b; Mochizuchi and Yamakawa, 1979; Ohta and Chuong, 1975; Phatak and Wittwer, 1965). Growing grafted vegetables, compared to growing grafted trees, is seldom practiced in the United States or in other western countries where land use is not intensive, i.e., proper crop rotation is being practiced. However, it is highly popular in Korea, Japan, and some Asian and European countries where land use is very intensive and the farming area is small (Hartmann and Kester, 1975). The purpose of this article is to briefly describe the cultivation of grafted vegetables and to summarize relevant information on grafting and cultivating grafted seedlings.

Received for publication 7 Apr. 1993. Accepted for publication 31 Aug. 1993. The cost of publishing this paper was defrayed in part by the payment of page charges. Under postal regulations, this paper therefore must be hereby marked advertisement solely to indicate this fact.

'Professor.

\section{CULTIVATION STATISTICS FOR SELECTED VEGETABLES AND GRAFTED SEEDLINGS}

Table 1 shows the statistics of cultivated vegetable area, cultivated area using grafted seedlings, and the estimated number of grafted vegetable seedlings in Korea and Japan. About 337 million grafted seedlings are planted annually in Korea and $\approx 651$ million in Japan (field and greenhouses). More than $95 \%$ of the watermelons in both countries are grafted. The majority of greenhouse cucumbers are grafted, but only $\approx 10 \%$ to $30 \%$ of cucumbers for growth in the field are grafted. Most of the Oriental melons are grafted to squash (Cucurbita spp.) rootstock (Ito, 1992; Jang et al., 1992). It is likely that these quantities will be increased soon with the introduction of new uses of grafting for other vegetables and the development of rootstock having desirable characteristics.

\section{VEGETABLES AND ROOTSTOCKS BEING GRAFTED}

Grafting's early purpose was to avoid or reduce the soilborne disease caused by $F$. oxysporum, but the reasons for grafting, as well as the kinds of vegetables grafted, have increased dramatically. Watermelons, other melons (Cucumis spp.), Oriental melons, cucumbers, tomatoes (Lycopersicon esculentum Mill.), and eggplants (Solanum melongena L.) are commonly grafted to various rootstock, especially for cultivation in greenhouses or plastic houses (Table 2). Numerous rootstock also have been developed. Watermelons are commonly grafted to gourd [Lagernaria siceraria (Mol.) Standl.] or to interspecific hybrids [C. maxima Duch. $\times$ C. moschata (Duch.) Duch. ex Poir.]. Cucumbers are most frequently grafted to figleaf gourd ( $C$. ficifolia Bouché) or interspecific hybrids (C. maxima $\times$ C. moschata).

However, many rootstock having distinctive characteristics are available today (Yamakawa, 1983), and growers select the rootstock they think are the most suitable for their growing season, cultivation methods (field or greenhouses), soil environments, and the type of crops and cultivars (Hirata, 1975; Jeong, 1986; Kato and Lou, 1989; Lee, 1989; Pisarczyk, 1983). For example, cucumbers grown in greenhouses during the cool season should be grafted onto figleaf gourd; however, those grown during the hot summer season are usually grafted onto Sintozwa rootstock (interspecific hybrids) or othes (Lee, 1989; Yoon, 1986).

Table 1. Estimated cultivation area of some vegetables being grafted and the number of grafted seedlings needed annually in Japan and Korea (Food and Agriculture Organization, 1992; Itagi, 1992; Ministry of Agriculture, Forestry, and Fisheries, 1992).

\begin{tabular}{|c|c|c|c|c|c|c|}
\hline \multirow[b]{2}{*}{ Vegetables } & \multicolumn{3}{|c|}{ Japan } & \multicolumn{3}{|c|}{ Korea } \\
\hline & $\begin{array}{c}\text { Total } \\
\text { cultivation } \\
\text { area } \\
\text { (ha, 1000s) }\end{array}$ & $\begin{array}{l}\text { Cultivation } \\
\text { area of } \\
\text { grafted } \\
\text { seedlings } \\
(\text { ha, } 1000 \mathrm{~s})\end{array}$ & $\begin{array}{c}\text { No. } \\
\text { grafted } \\
\text { seedlings } \\
\text { required } \text { d }^{2, y} \\
\text { (millions) }\end{array}$ & $\begin{array}{c}\text { Total } \\
\text { cultivation } \\
\text { area } \\
\text { (ha, } 1000 \mathrm{~s})\end{array}$ & $\begin{array}{l}\text { Cultivation } \\
\text { area of } \\
\text { grafted } \\
\text { seedlings } \\
\text { (ha, 1000s) }\end{array}$ & $\begin{array}{c}\text { No. } \\
\text { grafted } \\
\text { seedlings } \\
\text { required } \\
\text { (millions) }\end{array}$ \\
\hline \multicolumn{7}{|l|}{ Watermelon } \\
\hline Field & 24.9 & 23.8 & 71.4 & 28.3 & 26.9 & 80.7 \\
\hline Greenhouse & 3.2 & 3.2 & 9.6 & 7.4 & 7.4 & 22.1 \\
\hline \multicolumn{7}{|l|}{ Cucumber } \\
\hline Field & 14.8 & 4.6 & 137.2 & 3.8 & 0.4 & 13.5 \\
\hline Greenhouse & 7.0 & 6.0 & 216.1 & 4.7 & 3.3 & 78.4 \\
\hline \multicolumn{7}{|l|}{ Oriental melon } \\
\hline Field & 5.5 & 3.7 & 56.2 & 3.9 & 3.3 & 50.0 \\
\hline Greenhouse & 2.2 & 2.0 & 35.3 & 5.0 & 5.0 & 89.4 \\
\hline \multicolumn{7}{|l|}{$\begin{array}{l}\text { Melons and } \\
\text { muskmelons }\end{array}$} \\
\hline Field & --- & --- & -- & --- & --- & -- \\
\hline Greenhouse & 1.2 & 0.5 & 23.8 & 0.2 & 0.02 & 1.0 \\
\hline \multicolumn{7}{|l|}{ Tomato } \\
\hline Field & 6.9 & 0.3 & 12.8 & 0.6 & --- & --- \\
\hline Greenhouse & 5.0 & 0.8 & 36.9 & 1.9 & 0.04 & 1.7 \\
\hline \multicolumn{7}{|l|}{ Eggplant } \\
\hline Field & 13.3 & 2.7 & 32.1 & 1.2 & --- & --- \\
\hline Greenhouse & 1.7 & 1.6 & 19.7 & 0.1 & $\ldots$ & --- \\
\hline \multicolumn{7}{|l|}{ Total } \\
\hline Field & 65.6 & 35.1 & 309.7 & 37.8 & 30.6 & 144.2 \\
\hline Greenhouse & 20.3 & 14.1 & 341.4 & 19.3 & 15.7 & 192.6 \\
\hline
\end{tabular}

The quantity actually needed could be $\approx 15 \%$ higher than the numbers listed.

${ }^{y}$ Mostly for cultivation in plastic houses.

HortScience, Vol. 29(4), ApriL 1994 
Several new rootstock are being developed. For example, bur-cucumber (Sicyos angulatus L.) collected near Andong, Korea, showed good compatibility with cucumbers and watermelons for early summer growth and good resistance to nematodes (Choi et al, 1992; Kang et al., 1992; Lee, 1992; Lee et al., 1992).

\section{GRAFTING METHODS}

Various grafting methods have been developed and growers must choose their favorite methods based on experiences and preferences. Grafting cucurbitaceous crops is commonly done when scion and rootstock seedlings are young, i.e., before the outgrowth of the first true leaf between the cotyledons. Some of the most widely practiced grafting methods are shown in Fig. 1. Grafting methods vary considerably with the type of crops being grafted, and the sowing time for scion and stock seeds vary with grafting method and crop. For example, "hole insertion grafting" would be convenient for watermelons because of their small seedling size compared to the size of stock seedlings, such as gourd and squash. In cucumbers, however, "tongue approach grafting" has been used widely, mainly because of their large seedling size, including hypocotyl length and diameter, and grafting ease.

In the past, grafting was routinely carried out by the growers themselves, but it is now rapidly shifting to cooperative operations owing to the efficiency, ease of postgraft care, and recent expansion of the commercial seedling industry (such as sales of plug-grown seedlings). Even though the single-edged razor blade is still the most widely used grafting knife among farmers today, many other devices, such as specifically designed knives, clips, tubes, or glue, have now been developed for easier grafting and postgraft care (Holt, 1958; Itagi, 1992; Ito, 1992; Kurata, 1994; Morita, 1988; Obeidy and Smith, 1991; Oda and Nakayama, 1992; Oda et al., 1990; Ohta, 1977; Zaiter et al., 1987). Semi-automatic grafting machines and/or fully automatic grafting machines using robots (Itagi, 1992; Ito, 1992; Kobayashi, 1991) are being developed. By using the most sophisticated machine, grafting efficiency could be significantly increased from the present 150 seedlings/hour per expert.

The labor required for intensive postgraft care, mostly 7 to 10 days of careful management, could be markedly reduced by using specifically designed conditioning chambers (Ito, 1992). Kurata (1994) describes four methods of robot grafting in detail in Part II.

\section{OBJECTIVES OF GRAFTING VEGETABLES}

\section{Disease tolerance}

The vigorous roots of the rootstock exhibit excellent tolerance to serious soilborne diseases, such as those caused by Fusarium, Verticillium, and Pseudomonas (Table 3), even
Table 2. Rootstock, major grafting methods, and purpose of grafting for some vegetables.

\begin{tabular}{|c|c|c|c|}
\hline Vegetables & Popular rootstock species ${ }^{z}$ & $\begin{array}{l}\text { Grafting } \\
\text { methods }^{\mathrm{y}}\end{array}$ & Purpose ${ }^{x}$ \\
\hline \multirow[t]{6}{*}{ Watermelon } & Gourd (Lagernaria siceraria var. hispida) & 1 & 1,2 \\
\hline & Interspecific hybrids ${ }^{w}$ & 1,2 & $1,2,3$ \\
\hline & Wax gourd (Benincasa hispida Cogn.) & 1,3 & 1,2 \\
\hline & Pumpkin (Cucurbita pepo L.) & 2,3 & $1,2,3$ \\
\hline & Squash (Cucurbita moschata L.) & 1,2 & $1,2,3$ \\
\hline & Sicyos angulatus & 2 & 5 \\
\hline \multirow[t]{5}{*}{ Cucumber } & Figleaf gourd (Cucurbita ficifolia) & 2 & $1,2,3$ \\
\hline & Interspecific hybrids ${ }^{\mathrm{w}}$ & 1,2 & $1,2,3$ \\
\hline & $\mathrm{F}_{1}$ (Cucurbita maxima $\times$ C. moschata $)$ & 2 & $1,2,4$ \\
\hline & Cucumber (Cucumis sativus) & 2 & 1,2 \\
\hline & Sicyos angulatus & 2 & 2,5 \\
\hline \multirow[t]{3}{*}{ Oriental melon ${ }^{\mathrm{v}}$} & Interspecific hybrids ${ }^{w}$ & 2 & $1,2,3$ \\
\hline & Cucurbita moschata & 2 & $1,2,3$ \\
\hline & Cucumis melo & 3 & 3,4 \\
\hline Melons & Cucumis melo & 2,3 & 1 \\
\hline \multirow[t]{3}{*}{ Tomato } & Lycopersicon pimpinellifolium (L.) Mill. & 3 & 5 \\
\hline & Lycopersicon hirsutum Humb. \& Bonpl. & 3 & 5 \\
\hline & Lycopersicon esculentum & -. & 5 \\
\hline \multirow{2}{*}{ Eggplant } & Solanum integrifolium Poir & 2,3 & 6 \\
\hline & Solanum torvum $\mathrm{Sw}$. & 2,3 & 7 \\
\hline
\end{tabular}

${ }^{{ }^{2}}$ The names of the numerous varieties within the same species were not listed.

${ }^{y}$ Grafting methods: 1 = hole insertion; 2 = tongue approach; 3 = cleft grafting (see Fig. 1 for details).

xPurpose of grafting: 1 = fusarium wilt control; 2 = growth promotion; 3 = low-temperature tolerance; 4 = growth period extension; $5=$ nematode resistance; $6=$ bacterial wilt control; $7=$ virus infection reduction. "Many interspecific hybrids are commonly obtained by fertilized ovule culture in vitro.

"This melon, Cucumis melo var. makuwa Makino, is grown extensively in Korea and Japan.
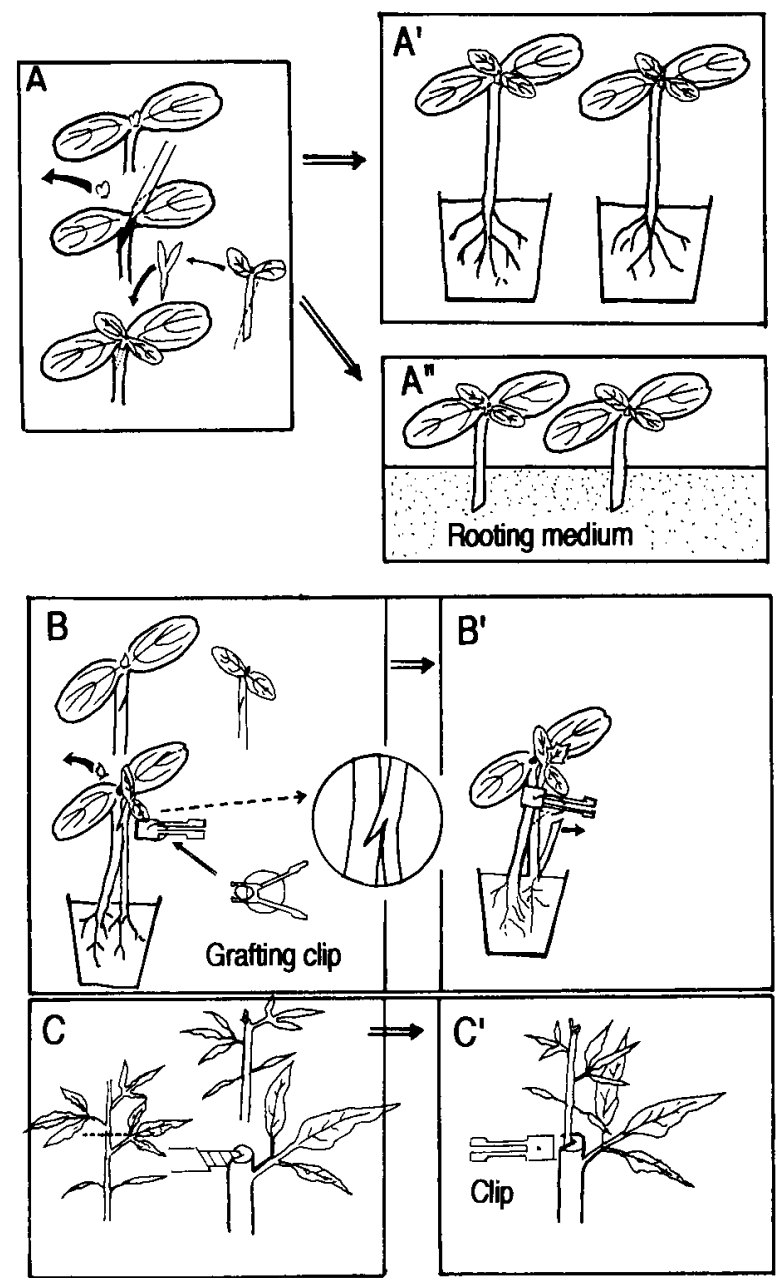

Fig. 1. Common grafting methods, (A) Hole insertion grafting. (A') Grafted seedlings are transplanted in not for further growth. (A") Rootstock are cut just above the root zone and then grafted as in (A). Grafted seedlings are then rooted in rooting medium while healing takes place.(B) Tongue approach grafting. (B') Grafting clip is used to adhere the graft union. The scion's hypocotyl is cut below the graft union $\approx 1$ week after grafting, $(\mathbf{C})$ Cleft grafting. $\left(\mathbf{C}^{\prime}\right)$ Specifically devised grafting clips are used to hold the scion and stock together tightly. 
though the degree of tolerance varies considerably with the rootstock. The mechanism of disease resistance, however, has not been intensively investigated. The disease tolerance in grafted seedlings maybe entirely due to the tolerance of stock plant roots to such diseases.

However, in actual plantings, adventitious rooting from the scion is very common (Lee, 1989). Plants having the root systems of the scion and rootstock are expected to be easily infected by soilborne diseases. However, seedlings having dual root systems often exhibit excellent disease resistance, almost comparable to those having only rootstock roots. This observation partially supports the previous report that substances associated with Fusarium tolerance are synthesized in the root and translocated to the scion through the xylem (Biles et al., 1989). The activity of the substances related to disease resistance may vary during the developmental stages of the grafted plants (Heo, 1991; Padgett and Morrison, 1990) .More research is needed in this regard. It is generally accepted that the disease-susceptible characteristics of the scion are not translocated to the rootstock.

\section{Growth promotion and yield increases}

The rootstock's vigorous root system is often capable of absorbing water and nutrients more efficiently than scion roots and serves as a good supplier of endogenous plant hormones (Heo, 1991; Jang et al., 1992; Kato and Lou, 1989; Park, 1987; Takahashi et al., 1981; Young, 1989). Cytokinins are the major plant hormones known to be synthesized principally in the roots (Chailakhyan and Khrianin, 1987). Cucurbitaceous crops usually show a significant amount of xylem sap when the vine is cut off after considerable growth. This xylem sap, which is greatly influenced by the rootstock even in the same scion cultivars, is known to contain fairly high concentrations of minerals, organic substances, and plant hormones such as cytokinins and gibberellins (GA) (Biles et al., 1989; Jang et al., 1992; Masuda, 1989; Masuda and Gomi, 1982, 1984; Masuda et al., 1981). Cytokinin contents are high in xylem sap, reaching 20 to $50 \mathrm{ng} \cdot \mathrm{ml}^{-1}$ in eggplant (Kato and Lou, 1989), 0.10 to 0.18 $\mathrm{mg} \cdot$ liter $^{-1}$ in cucumbers (Park and Kate, 1986), or up to 20 to $50 \mathrm{mg} \cdot \operatorname{liter}^{-1}(\mathrm{Heo}, 1991)$ in cucumber rootstock.

Kato and Lou (1989) examined the xylem sap and hormone concentrations in eggplants grafted onto various rootstock. The xylem sap bleeding rates were the highest in the eggplants grafted onto VF rootstock, followed by Torubamu and Akanasu rootstock. Intact eggplants showed the lowest xylem sap bleeding rates in two of the three cultivars (Table 4). Cytokinin (trans-zeatin) concentrations were highest in sap collected from eggplant grafted onto VF rootstock. Cytokinin concentrations were lowest in sap collected from plants grafted onto Torubamu rootstock, thus clearly showing the role of rootstock on cytokinin production and supply. GA concentrations in xylem sap were lowest in plants grafted onto Akanasu rootstock, and indole acetic acid (IAA) con-

Table 3. Rootstocks for tomato and their specific resistance to some selected soilborne diseases (Yamakawa, 1983).

\begin{tabular}{|c|c|c|c|c|c|c|}
\hline \multirow[b]{2}{*}{$\begin{array}{l}\text { Rootstocks } \\
\text { for tomato }\end{array}$} & \multicolumn{6}{|c|}{ Major tomato diseases } \\
\hline & $\begin{array}{c}\text { Pseudomonas } \\
\text { solanacearum } \\
\text { (E.F.) Smith }\end{array}$ & $\begin{array}{l}\text { Fusarium } \\
\text { oxysporum } \\
\text { (Schlect.) }\end{array}$ & $\begin{array}{c}\text { Verticillium } \\
\text { dahliae } \\
\text { Kleb. }\end{array}$ & $\begin{array}{c}\text { Pyrenochaeta } \\
\text { lycopersici } \\
\text { Schn. \& Gerl. }\end{array}$ & $\begin{array}{l}\text { Root knot } \\
\text { nematode }\end{array}$ & $\begin{array}{c}\text { Tobacco } \\
\text { mosaic } \\
\text { virus }\end{array}$ \\
\hline$\overline{\mathrm{BF}}$ & $\mathrm{R}^{z}$ & $\mathbf{R}$ & $\mathrm{S}$ & $\mathrm{S}$ & $\mathrm{S}$ & $\mathrm{S}$ \\
\hline LS 89 & $\mathrm{R}$ & $\mathbf{R}$ & $S$ & $S$ & $\mathrm{~S}$ & S \\
\hline PFN & $\mathrm{R}$ & $\mathbf{R}$ & $S$ & $S$ & $\mathrm{R}$ & $S$ \\
\hline PFNT & $\mathrm{R}$ & $\mathbf{R}$ & $S$ & $S$ & $\mathrm{R}$ & $\mathrm{R}$ \\
\hline KNVF & $S$ & $\mathrm{R}$ & $\mathbf{R}$ & $\mathbf{R}$ & $\mathrm{R}$ & $\mathrm{R}$ \\
\hline \multicolumn{7}{|l|}{ KNVF Tm } \\
\hline Signaal & $\mathrm{S}$ & $\mathrm{R}$ & $\mathrm{R}$ & $\mathbf{R}$ & $\mathrm{R}$ & $\mathbf{R}$ \\
\hline KCFT-N & S & R & $S$ & $\mathrm{R}$ & $\mathrm{R}$ & $\mathrm{R}$ \\
\hline
\end{tabular}

${ }^{{ }^{x} \mathrm{R}}=$ resistant; $\mathrm{S}=$ susceptible.

Table 4. Endogenous hormone concentration in bleeding xylem sap ${ }^{z}$ of eggplants as influenced by rootstocks (Kato and Lou, 1989).

\begin{tabular}{|c|c|c|c|c|c|c|}
\hline \multirow{2}{*}{$\begin{array}{l}\text { Scion } \\
\text { cultivar }\end{array}$} & \multirow[b]{2}{*}{ Rootstocks } & \multirow{2}{*}{$\begin{array}{c}\text { Xylem } \\
\text { exudation } \\
\text { rate } \\
(\mathrm{ml} / \text { plant per } \mathrm{h}) \\
\end{array}$} & \multicolumn{4}{|c|}{ Hormone concn in $\operatorname{sap}^{y}\left(n g \cdot m l^{-1}\right)$} \\
\hline & & & t-Zeatin & $\mathrm{GA}$ & IAA & $\overline{\mathrm{ABA}^{\mathrm{x}}}$ \\
\hline \multirow[t]{4}{*}{ Hayabusa } & VF & 6.70 & 41 & 1.91 & 168 & 78 \\
\hline & Akanasu & 5.62 & 29 & 0.59 & 193 & 40 \\
\hline & Torubamu & 6.07 & 21 & 0.99 & 133 & 84 \\
\hline & Own root & 2.38 & 22 & 0.47 & 98 & 118 \\
\hline \multirow[t]{4}{*}{ Kokuyou } & VF & 6.62 & 46 & 2.13 & 283 & 70 \\
\hline & Akanasu & 5.58 & 22 & 0.57 & 285 & 48 \\
\hline & Torubamu & 6.11 & 20 & 1.09 & 173 & 73 \\
\hline & Own root & 2.86 & 32 & 0.79 & 96 & 112 \\
\hline \multirow[t]{4}{*}{ Beikoku daimaru } & VF & 6.68 & 48 & 1.58 & 371 & 65 \\
\hline & Akanasu & 4.93 & 41 & 0.86 & 480 & 49 \\
\hline & Torubamu & 4.68 & 29 & 0.87 & 356 & 70 \\
\hline & Own root & 5.28 & 38 & 0.73 & 165 & 46 \\
\hline
\end{tabular}

${ }^{2}$ Collected from the remaining stem base after removing the shoot.

yetermined with high-performance liquid chromatography (cytokinins, ABA, and IAA) or lettuce hypocotyl elongation bioassay (gibberellins).

${ }^{\times} \mathrm{ABA}=$ abscisic acid.

centrations were lowest in intact plants. Kato and Lou also reported that eggplant yield was positively correlated with the amount of $x y-$ lem sap exudate.

The prolonged duration of fruit harvest in grafted plants is believed to be due not only to the disease tolerance of the rootstock, but also to enhanced water and mineral uptake (Gomi and Masuda, 1981; Kim and Lee, 1989; Masuda, 1989; Masuda and Gomi, 1982). The yield increases, obtained by the extended duration of fruit harvest, are most apparent under the unfavorable environments of protected cultivation. However, it should be remembered that the rootstock effect varies greatly with scion cultivar, even in the same crop. For example, the most widely used warm-season rootstock, Sintozwa (an interspecific hybrid), failed to promote the seedling growth or increased fruit yield of those cucumber cultivars well-adapted to summer growth and having larger root systems, even though the yields of other cucumber cultivars were significantly increased by the same rootstock during the summer (Jeong and Lee, 1986). Nicotine accumulation in tobacco (Nicotiana tabacum L.) leaves was greatly affected by the rootstock (Dawson, 1942; Lee et al., 1982).

\section{Effect on fruit quality}

The fruit size of watermelons grafted to rootstock having vigorous root systems is often significantly increased compared to fruit from intact plants, and many growers are practicing grafting mainly for this reason. However, it is well known that other quality characteristics, such as fruit shape and skin color, skin or rind smoothness, flesh texture and color, rind thickness, and soluble solids concentration are influenced by rootstock, even though the same cultural treatments, such as fertilizer application and irrigation, are practiced. In cucumbers, especially those for export, external color and bloom development are important quality factors (Choi et al., 1992; Kang et al., 1992). Even though these are usually regarded as cultivar-specific hereditary characteristics, they can be greatly influenced by the rootstock (Heo, 1991; Kang et al., 1992). However, the effects of rootstock on fruit quality are often detrimental, except for fruit size (Table 5), and, therefore, most newly devised growing recommendations are aimed at minimizing the detrimental effects of rootstock on fruit quality.

\section{ROLE OF ROOTSTOCKS}

Even though there is little or no information on the translocation of agents from scion to rootstock, there are many reports concerning the translocation of agents from rootstock to scion. Some permanent changes take place in the scion, induced by transmissible agents from the rootstock (Dole and Wilkins, 1991, 
Table 5. Problems associated with grafting and cultivating grafted vegetable seedlings.

\begin{tabular}{|c|c|c|}
\hline Factors & Category & Possible mitigating measures \\
\hline \multirow[t]{2}{*}{ Labor } & Grafting operation & $\begin{array}{l}\text { Specifically designed knives, grafting apparatus, } \\
\text { grafting machines, grafting robots }\end{array}$ \\
\hline & Postgraft care & $\begin{array}{l}\text { Experience needed and postgraft conditioning } \\
\text { chamber may be required for automation }\end{array}$ \\
\hline Techniques & Rootstocks & $\begin{array}{l}\text { Wise selection of rootstock suitable } \\
\text { for type of crops and cultivars }\end{array}$ \\
\hline Management & Fertilizer application & $\begin{array}{l}\text { Different field management, especially reduced } \\
\text { fertilizer application }\end{array}$ \\
\hline Compatibility & Uneven senescence & $\begin{array}{l}\text { Proper timing of growing season and } \\
\text { rootstock type and selection }\end{array}$ \\
\hline \multirow[t]{2}{*}{ Growth } & Excessive vegetative growth & Reduced fertilizer and soil moisture \\
\hline & Physiological disorders & $\begin{array}{l}\text { Wise selection of rootstocks to reduce } \\
\text { excessive water and nutrient uptake }\end{array}$ \\
\hline \multirow{6}{*}{ Fruit quality } & Size and shape & Partly controlled with rootstocks \\
\hline & Appearance & Proper cultural management \\
\hline & Insipid taste & Cultivar and rootstock selection \\
\hline & Soluble solids & Proper soil moisture control \\
\hline & Yellow band in flesh & May appear in red flesh of watermelon \\
\hline & Internal decay & Foliar $\mathrm{Ca}$ application and reduced $\mathrm{N}$ \\
\hline Expense & Rootstock seeds & $\begin{array}{l}\text { Inexpensive rootstock seeds } \\
\text { (domestic or imported) }\end{array}$ \\
\hline \multirow[t]{2}{*}{ Scion rooting } & External rooting & $\begin{array}{l}\text { Careful management during } \\
\text { seedling stage and at transplanting }\end{array}$ \\
\hline & Internal or fused rooting & $\begin{array}{l}\text { Different grafting methods to avoid scion } \\
\text { root development through internal } \\
\text { cavity of rootstock hypocotyl, which } \\
\text { often cannot be recognized externally }\end{array}$ \\
\hline
\end{tabular}

1992; Fajnbron, 1953; Frankel, 1970; Hirata, 1980; Hirata et al., 1986; Ohta, 1977; Ohta and Chuong, 1975; Yagishita, 1961; Yagishita et al., 1985). This rootstock-induced transformation in the scion is maintained through generations via stem cuttings or through selfpollinated seeds. The transformation may be partially overcome by high-temperature treatment (Dole and Wilkins, 1991). Sex expression in cucurbitaceous crops may be influenced by rootstock (Chailakhyan and Khrianin, 1987; Friendlander et al., 1977; Park, 1987; Takahashi et al., 1981). However, because the major hormones supplied by rootstock are cytokinins and sex expression in cucurbitaceous crops is mostly controlled by gibberellins or internal ethylene (Ying and Narayanan, 1991), the effect of rootstock on sex expression is often not as significant as changes in other characteristics.

Low-temperature tolerance of the rootstock is one of the most desirable characteristics for vegetable cultivation in plastic houses during winter or early spring. Scion growth of cucumber can be promoted significantly by simple grafting onto figleaf gourd (Kang et al., 1992; Lee, 1989). Figleaf gourd roots can absorb water and nutrients more efficiently than intact cucumber roots; this increased absorption was correlated with the increased cytochrome respiration rate coupled with oxidative phosphorylation in the cytochrome system (Tachibana, 1982, 1988, 1989).

Grafting in solanaceous crops maybe practiced for other purposes. Tomatoes are usually grafted onto other tomatoes having different characteristics (Table 3). However, tomatoes and sometimes peppers (Capsicum annuum L.), can be easily grafted onto eggplant, potato (Solanum tuberosum L.), or other solanaceous crops (Dawson, 1942; Fajnbron, 1953; Hirata,
1975, 1980; Hirata et al., 1986; Lowman and Kelly, 1946; Matsuzoe et al., 1991a; Mochizuki and Yamakawa, 1979). Thus, when tomatoes are grafted onto potato rootstock, considerable yield of both tomatoes and potatoes can be obtained. However, this practice is not popular among farmers because of the considerable delay in harvest date, especially in potatoes (Ra et al., 1992).

Grafting is also conducted to study the movement of some endogenous flowering substances across the graft union, and it has been proven that the flower-inducing stimuli controlled by photoperiod moved easily through the graft union, whereas the stimuli induced by low-temperature treatment or vernalization did not (Chailakhyan and Khrianin, 1987). Grafting herbaceous plants is performed for other purposes, such as to study virus transmission and stock-scion physiology (Chailakhyan and Khrianin, 1987; Hartmann and Kester, 1975; Oda et al., 1990; Stimart, 1983; Yagishita et al., 1985; Zaiter et al., 1987).

\section{PROBLEMS ASSOCIATED WITH GRAFTING}

Various problems are commonly associated with grafting and cultivating grafted seedlings (Table 5). Major problems are the labor and techniques required for the grafting operation and postgraft handling of grafted seedlings for rapid healing for $\approx 7$ to 10 days. An expert can graft 1200 seedlings per day (150 seedlings per hour), but the numbers vary with the grafting method. Similarly, the postgraft handling method depends mostly on the grafting methods. In general, the problems listed in Table 5 could be minimized or easily overcome by careful cultural management and wise selection of scion and rootstock cultivars.

\section{CONCLUSION}

Even though there are many problems associated with cultivating grafted vegetable seedlings, the need for successfully grafted seedlings is growing rapidly. Breeding multipurpose rootstock and developing efficient grafting machines and techniques will undoubtedly encourage increased use of grafted seedlings not only in Korea and Japan, but also in many other countries. Large-scale commercial production of vegetable seedlings is expanding rapidly in many developed countries, and this will lead to an increased commercial supply and use of grafted vegetable seedlings throughout the world.

\section{Literature Cited}

Ali, M., N, Matsuo, H. Okubo, and K. Fujieda. 1991, Resistance of non-tuberous Solanum to rootknot nematode. J. Jpn. Soc. Hort. Sci, 60(4):921926.

Ashita, E. (ed.). 1927, Grafting of watermelons (in Japanese). Korea (Chosun) Agr. Nwsl. 1:9.

Biles, C.L.,-R.D. Martyn, and H.D. Wilson. 1989. Isozymes and general proteins from various watermelon cultivars and tissue types. HortScience 24(5):810-812.

Chailakhyan, M.Kh. and V.N. Khrianin. 1987. Influence of environmental factors and nutrition on sex determination in plants: A review, p. 3132. In: K. Thimann (ed.). Sexuality in plants and its hormonal regulation. Springer-Verlag, New York.

Choi, J.S., K.R. Kang, K.H. Kang, and S.S. Lee. 1992. Selection of cultivars and improvement of cultivation techniques for promoting export of cucumbers (in Korean with English summary). Res. Rpt., Min. Sci, \& Technol., Seoul, Republic of Korea, p. 74

Choi, K.S., Y.H. Um, D.Y. Park, S.S. Lee, and C.H. Lee. 1980. 'Wonkyo 601', a newly bred interspecific rootstock for cucurbits (in Korean with English summary), Res. Rpt, Rural Development Admin., Suwon, Republic of Korea.

Dawson, R,F. 1942. Accumulation of nicotine in reciprocal grafts of tomato and tobacco. Amer. J, Bot. 29:66-71.

Dole, J.M. and H,F, Wilkins. 1992. In vivo characterization of a graft-transmissible, free-branching agent in poinsettia, J, Amer. Soc. Hort. Sci, 117(6):972-975.

Fajnbron, B. 1953. Heritable changes in tomatoes under the influence of grafting (in Russian). Ak. Nauk. USSR, Moscow, Inst. Genetiki. Trudy. 200:210-240

Food and Agriculture Organization of the United Nations. 1992. FAO production yearbook. Food \& Agr. Organiz. of the United Nations, Rome.

Frankel, R. 1970. Genetic evidence in alternative maternal and Mendelian hereditary elements in Petunia hybrids. Heredity 26:107-119.

Friedlander, M., D. Atamon, and E. Galun. 1977. The effect of grafting on sex expression in cucumber. Plant \& Cell Physiol. 18:1343-1350.

Gomi, K. and M. Masuda. 1981, Studies on the characteristics of nutrient absorption of rootstock in grafting fruit vegetables. I. Magnesium deficiency of leaves of cucumber as affected by a rootstock, C. ficifolia and potassium concentration in culture solution (in Japanese with English summary). Bul, Fac, Agr., Miyazaki Univ., Miyazaki, Japan. 27(2):179-186.

Hartmann, H.T. and D.E. Kester. 1975. Plant propagation: Principles and practices. 3rd ed. PrenticeHall, Englewood Cliffs, N.J. 
Heo, Y.C. 1991. Effects of rootstock on exudation and mineral elements contents in different parts of Oriental melon and cucumber (in Korean with English summary). MS thesis, Kyung Hee Univ., Seoul, Korea. p. 53,

Hirata, Y. 1975. Graft experiment in solanaceous plant. I. J. Michrin Biol. 11:69-75.

Hirata, Y. 1980. Graft-induced changes in skin and flesh color in tomato (Lycopersicon esculentum Mill.). J. Jpn. Soc. Hort. Sci. 49(2):211-216.

Hirata, Y., N. Yagishita, L. Ledoux, M. Thiry, and L. Pilels. 1986. Graft-induced changes in pepper and eggplant. Eucarpia (Zaragoza) p. 19-23.

Holt, J. 1958, A simple way of grafting herbaceous plant, Garden Chron. (c.f. Hartmann and Kester. 1983. Plant propagation. 4th ed. p. 386.)

Itagi, T. 1992. Status of transplant production systems in Japan and new grafting technics (in Korean). Symp. Protected Hort. Hort. Expt. Sta., Rural Development Admin., Suwon, Republic of Korea. p. 32-67.

Ito, T. 1992. Present state of transplant production practices in Japanese horticultural industry, $\mathrm{p}$. 65-82. In: K. Kurata and T. Kozai (eds.). Transplant production system. Kluwer Academic Publishers, Yokohama, Japan,

Jang, K.U., et al. 1992. Utilization of sap and fruit juice of Luffa cylindrica L. Res. Rpt., Korean Ginseng and Tobacco Inst., Taejon. p. 116.

Jeong, S.J. 1986. Effects of several rootstock on the growth, fruit yield and quality of two cucumber cultivars (in Korean with English summary). Inst. Food Development, Kyung Hee Univ., Suwon, Korea, Res. Collection 7:67-76.

Jeong, S.J. and J. M. Lee. 1986. Effect of rootstocks and growth regulator treatments on the growth and yield of fall-sown cucumbers (Cucumis sativus Cv. Summer Samchuck) (in Korean with English summary). Inst. Food Development, Kyung Hee Univ., Suwon, Korea. Res. Collection 7:77-87.

Kang, K.S., S.S. Choe, and S.S. Lee. 1992. Studies on rootstock for stable production of cucumber (in Korean with tables and figures in English). Kor. Soc. Hort. Sci. 19(2):122-123. (Abstr.)

Kate, T. and H. Lou. 1989. Effect of rootstock on the yield, mineral nutrition and hormone level in xylem sap in eggplant. J. Jpn. Soc. Hort. Sci. 58(2):345-352.

Kim, S.E. and J.M. Lee. 1989. Effect of rootstocks and fertilizers on the growth and mineral contents in cucumber (Cucumis sativus L.) (in Korean with English summary). Inst. Food Development, Kyung Hee Univ., Suwon, Korea. Res. Collection 10:75-82.

Kobayashi, K. 1991. Development of a grafting robot for the fruit-vegetables. Plant Cell Technol. 3(6):477-482.

Kurata, K, 1992. Transplant production robots in Japan, p.313-329. In: K. Kurata and T. Kozai (eds.). Transplant production system. Kluwer Academic Publishers, Yokohama, Japan.

Kurata, K. 1994. Cultivation of grafted vegetables. II. Development of grafting robots in Japan. HortScience 29:240-244.

Lee, J.M. 1989. On the cultivation of grafted plants of cucurbitaceous vegetables (in Korean with English summary), J. Kor. Soc. Hort. Sci. 30(3):169-179.

Lee, S.H., S.Y. Jeh, and K.U. Kim. 1982. Growth and chemical components of reciprocally grafted tobacco cultivars between Hyangchio and L.A. Burley 21.J.Kor. Soc. Tobacco Sci. 4(2):74-79.

Lee, W.Y. 1992. Use of Sicyos angulatus cv. Andong as rootstock for cucurbits (in Korean). Rura Development Admin., Suwon, Korea. Res. \& Extension 33(4):69-73.

Lee, W.Y., G.S. Hwang, C.G. Shin, H.T. Ha, and
J.M. Hwang. 1992. Yield performance test of watermelon (Citrullus vulgaris Schrad.) grafted onto the rootstock, Sicyos angulatus L. in the farm field (in Korean with tables and figures in English). Kor. Soc. Hort. Sci. 10(2):38-39. (Abstr.)

Lowman, M.S. and J.W. Kelly. 1946, The presence of mydriatic alkaroids in tomato fruits from scions grown on Datura .stranonium rootstock. Proc. Amer. Soc. Hort, Sci, 48:249-259.

Marukawa, S. and I. Takatsu. 1969. Studies on the selection of Cucurbita spp. as cucumber rootstock. Bul. Ibaraki Hort. Expt. Sta. 3:1118

Masuda, M. 1989. Mineral concentrations in xylem exudate of tomato and cucumber plants at midday and midnight (in Japanese with English summary). J. Jpn. Soc. Hort. Sci. 58(3):293298.

Masuda, M. and K. Gomi. 1982. Diurnal changes of the exudation rate and the mineral concentration in xylem sap after decapitation of grafted and non-grafted cucumber (in Japanese with English summary). J. Jpn. Soc. Hort. Sci. 51(3):293298.

Masuda, M. and K. Gomi. 1984. Mineral absorption and oxygen consumption in grafted and nongrafted cucumber (in Japanese with English summary). J. Jpn. Soc. Hort. Sci. 52(4):414419.

Masuda, M., T. Nakamura, and K. Gomi. 1981. Studies on the characteristics of nutrient absorption of rootstock in grafting of fruit vegetables. II. Effect of rootstock, C. ficifolia on the growth and mineral composition of xylem sap in cucumber in relation to potassium concentration in culture system. Bul. Fac. Agr., Miyazaki Univ., Miyazaki, Japan. 27(2):187-194.

Matsuzoe, N., M. Ali, H. Okubo, and K. Fujieda. 1991a. Growth behavior of tomato plants grafted on wild relatives of Solanum melongena. J. Jpn. Soc. Hort. Sci. 59(Suppl. 2):358-359.

Matsuzoe, N., M. Ali, H. Okubo, and K. Fujieda. 1991b. Resistance of tomato grafted on Solanum rootstock to bacterial wilt. J. Jpn. Soc. Hort. Sci. 60(Suppl. 2):176-177.

Ministry of Agriculture, Forestry, and Fisheries. 1992. Statistical yearbook of agriculture, forestry and fisheries. Min. Agr,, For., and Fisheries, Republic of Korea.

Mochizuki, H. and K. Yamakawa. 1979. Potential utilization of bacterial wilt resistant Solanum species as rootstock for eggplant production. Bul. Veg. Ornamental Crops Res. Sta. Ser. A. 7:11-18.

Morita, S. 1988. A new method of grafting by the application of adhesive in fruit vegetables (in Japanese). Agr. Hort. 63:1190-1196.

Obeidy, A.A. and M.A.L. Smith. 1991. A versatile new tactic for fruit tree micrografting. HortTechnology 1(1):91-95

Oda, M. and T. Nakayama. 1992. Adhesive grafting of Chinese cabbage on turnip. HortScience 27(10):1136.

Oda, M., K. Tsuji, and M. Nagaoka. 1990. Intergeneric, specific, and varietal grafting in Cruciferae. Proc. XXIII Intl. Hort. Congr. (1), Florence, Italy, 1990. p. 205.

Ohta, Y. 1977. Hereditary changes induced by grafting and by DNA application and their implication in Capsicum breeding. Agronomique, Avignon-Montavet, France. p. 147-154.

Ohta, Y. and R.V. Chuong. 1975. Hereditary changes in Capsicum annuиm L. induced by ordinary grafting. Euphytica 24:355-368

Padgett, M. and J.C. Morrison, 1990. Changes in grape berry exudates during fruit development and their effect on mycelial growth of Botrytis cinerea. J. Amer. Soc. Hort. Sci. 115(2):256257.

Park, H.Y. and T. Kato, 1986. Relation between branch development and amount of xylem exudate in cucumber. Jpn. Soc. Hort. Sci. (Fall 1986) p. 256-257. (Abstr.)

Park, Y.D. 1987. Effect of fertilizer levels, growth regulators and salt treatment on the growth and sex expression in cucumbers grafted to different rootstock (in Korean with English summary). MS thesis, Kyung Hee Univ., Suwon, Korea, p. 50.

Phatak, S.C. and S.H. Wittwer, 1965. Regulation of tomato flowering through reciprocal top-root grafting, Proc. Amer. Soc. Hort. Sci. 87:398403

Pisarzyk, J.M. 1983. Stock-scion interaction and tuber dry matter in potato. HortScience 18(2):244-245

Ra, S.W., H.K. Lee, J.S, Yang, J.S. Suh, E.S. Kim, E.M. Lee, C.S. Moon, and T.H. Rho. 1992 Studies on the graft cultivation of tomato and potato (in Korean with tables and figures in English). Kor. Soc. Hort. Sci. 19(2):46-47. (Abstr.)

Ryu, J.S., K.S. Choi, and S.S. Lee. 1973. Effects of grafting stocks on growth, quality and yields of watermelon (in Korean with English summary). J. Kor. Soc. Hort. Sci. 13:45-49.

Stimart, D.P. 1983. Promotion and inhibition of branching in poinsettia in grafts between selfbranching and non-branching cultivars. J. Amer. Soc. Hort. Sci. 108(3):419-422.

Tachibana, S. 1982. Comparison of effects of root temperature on the growth and mineral nutrition of cucumber cultivars and figleaf gourd. J. Jpn. Soc. Hort. Sci. 51(3):299-308.

Tachibana, S. 1988. The influence of root temperature on nitrate assimilation by cucumber and figleaf gourd. J. Jpn. Soc. Hort. Sci. 57(3):440447.

Tachibana, S. 1989. Respiratory response of detached roots to lower temperatures in cucumber and figleaf gourd grown at $20^{\circ} \mathrm{C}$ root temperature. J. Jpn. Soc. Hort. Sci. 58(2):333-337.

Takahasbi, H., T. Saito, and H. Suge. 1981. Intergeneria translocation of floral stimulus across a graft union in monoecious Cucurbitaceae with special reference to the sex expression in cucumber. Plant \& Cell Physiol. 23(1):1-9.

Yagishita, N. 1961, Studies on graft hybrids of Capsicum annuum L. II. Variation in fruit shape caused by grafting for three successive generations and the effects in the progeny. Bot. Mag. (Tokyo). 74:480-489.

Yagishita, S., Y. Hirata, J. Okochi, K. Kimura, H. Miukami, and H. Ohashi. 1985. Characterization of graft-induced change in capsaicin contents of Capsicum annuum L. Euphytica 34:297301.

Yamakawa, B. 1983, Grafting, p. 141-153. In: Nishi (ed.). Vegetable handbook (in Japanese). Yokendo Book Co., Tokyo.

Ying, Z. and K.R. Narayanan. 1991. Hormonal control in sex expression in Lagenaria. Plant Growth Regulat. Soc. Amer. 19(3):165.

Yoon, C.J. 1986. Effect of rootstock and soil temperatures on the growth of cucumber (in Korean). Res. Rpt. Hort., Rural Development Admin., Suwon, Korea. p. 307-311.

Young, E. 1989. Cytokinin and soluble carbohydrate concentrations in xylem sap of apple during dormancy and bud break. J. Amer. Soc. Hort. Sci. 114(2):297-300

Zaiter, H.Z., D.P. Coyne, and R.B. Clark. 1987. Temperature, grafting method, and rootstock influence on iron deficiency chlorosis of bean. J. Amer. Soc. Hort. Sci. 112(6):1023-1026. 